\title{
Uterine Corpus Adenosarcoma TNM
}

\section{Finding v8}

National Cancer Institute

\section{Source}

National Cancer Institute. Uterine Corpus Adenosarcoma TNM Finding v8. NCI

Thesaurus. Code C139842.

A finding about one or more characteristics of uterine corpus adenosarcoma, following the rules of the TNM AJCC V8 classification system. 